\title{
Cinematic Walls: Pedro Costa's Mural Imagination
}

\author{
ESTELA VIEIRA \\ Indiana University Bloomington
}

\begin{abstract}
This essay offers a reading of Pedro Costa's first feature-length film, O sangue (1989). It explores the representation of different sorts of walls, their semantic inferences and functions, arguing that Costa's "mural imagination" speaks to the limits—or perceived limitlessness —of contemporary filmmaking. I show that in $\mathrm{O}$ sangue, walls emerge as tools for defining realism and its relation to cinema. Beyond this, they work as rhetorical strategies to interrogate the threshold between fact and fiction and between socio-political realities and artistic filmmaking. For Costa, walls emphasize the authenticity of fictional worlds and highlight the ways in which audiences relate to the realities and communities represented on screen.
\end{abstract}

Keywords: O sangue; Denis Diderot; Georg Simmel; symbolism of walls; limits in cinema

One of the most comprehensive American retrospectives of the films of acclaimed contemporary Portuguese director Pedro Costa took place in 2011 at the Indiana University Cinema. The retrospective, titled "Films of Pedro Costa-The Artful Tableau of Everyday Life," included a public interview with the filmmaker. During the conversation, Costa admitted to being fascinated with walls, a fact that is likely evident to anyone who has seen his films, where real and symbolic walls continually stretch across the cinematic landscape. In fact, their presence and the allusions they make are, in my view, fundamental to understanding some of the ontological questions that most preoccupy Costa and the techniques he employs. As Akiva Gottlieb puts it: "Doors and walls are the central motif in Costa's work, and the barriers to entry are manifold and varied" 
(par. 3). While walls - whether man-made or natural, real or fictional, formal or contextual, psychological or sociological-become more explicit in Costa's Fontainhas trilogy; they are already central to his first feature-length film, $O$ sangue (1989) and play an important role in his Casa de lava (1994), as well. ${ }^{1}$ A complex "aesthetic of the wall" emerges in Costa's work that can help us to better understand some of his films' veiled meanings.

In the analysis that follows, I focus on Costa's first film, $O$ sangue, and explore the role and representation of different sorts of walls, with their semantic inferences and functions. My goal is to show how what I call Costa's "mural imagination" speaks to the limits - or perceived limitlessness - of contemporary filmmaking. I also argue that this motif only becomes more intense and explicit in the enclosed spaces and settings of Costa's later Fontainhas trilogy - the work that would receive numerous critical reviews and bring him international praise. ${ }^{2}$ These three films have as their constant background the houses and rooms of the soon-to-be-demolished Fontainhas neighborhood on the outskirts of Lisbon, along with the new low-income housing project that would replace them. Many of the characters and inhabitants of these settings and visual tableaus are Cape Verdean immigrants who moved to Portugal in the 1960s when the demand for unskilled labor intensified. These workers, often hired by the then-booming construction industry, were themselves responsible for a good deal of building in Lisbon, ranging from their own makeshift houses in poor neighborhoods like Fontainhas to the modernist Calouste Gulbenkian Museum and other emblematic spaces in the city. In an interview, Costa even compared the work of the filmmaker to that of the construction worker: "o cinema é muito difícil, muito cansativo. É um ofício, como ser pedreiro" (Cipriano 483).

Costa had not yet discovered Fontainhas when he set out to make $O$ sangue, yet his characteristic obsession with walls and his use of them for visual content and as cinematic methodology begins with this first feature. In $O$ sangue, cinematic walls emerge as tools for defining realism and its relation to

\footnotetext{
${ }^{1}$ Letters from Fontainhas: Three Films by Pedro Costa, released by the Criterion Collection in 2010, contains the trilogy, Ossos (1997), No quarto da Vanda (2000), and Juventude em marcha (2006). The box set, which was also the first DVD release of Costa's work in the United States, quickly brought him international acclaim.

${ }^{2}$ See Malveira (40-41) for a brief analysis of the representation of walls in Costa's trilogy.
} 
cinema, as well as a means of interrogating the threshold between fact and fiction along with that between socio-political realities and artistic filmmaking.

\section{The Fourth Wall}

Before turning to my reading of the film, I would like to refer to two different but related concepts. The first is the idea of the "fourth wall," a term attributed to French Enlightenment philosophe Denis Diderot (1713-1784). Diderot used this term to refer to the imaginary wall at the front of the stage in a traditional three-walled boxed theater. European drama up to the middle of the eighteenth century had relied on some form of interaction between actors and spectators; however, it was at this historical moment that playwrights and actors across the continent began to think differently about this relationship. According to Diderot, performers should begin to act as if the curtain had never been drawn, that is, as if in its place was an imaginary wall. In a 1758 essay on dramatic poetry, he argues: "When you write or act, think no more of the audience than if it had never existed. Imagine a huge wall across the front of the stage, separating you from the audience, and behave exactly as if the curtain had never risen" (231). Ironically, Diderot builds this conceptual wall to create a stronger connection between what happens on stage and in life. As he sees it, if the actors pretend that the audience is not there, they can act naturally. This translucent wall, in other words, was meant to help the viewers see the stage presentation as real although separate from them. For Helmut Schneider, Diderot's idea meant that "actors and audience were to suppress the consciousness of what they were doing - acting and watching" (386).

The concept of the "fourth wall" became dominant in theatrical practice only in the nineteenth century, and it has evolved directly from Diderot's initial conception. It eventually extended to all other genres, particularly to film, and it has come to refer to the imaginary boundary between any fictional work and its viewers/readers. When actors today speak directly to the audience or camera, it is commonly understood that they are "breaking the fourth wall." In his own account of Diderot's theory and its impact, Schneider focuses on how a new understanding of theater in the eighteenth century makes possible for the first time the representation of an abstract collective, given that the illusion of reality set on stage is in fact a form of acting out a community, albeit in theoretical 
terms. As Schneider argues, the creation of this abstract fictional wall between the reality on the stage and that of the audience is necessary for Diderot insofar as it is what he believes enables the spectator to empathize with what $\mathrm{s} / \mathrm{he}$ witnesses on stage. I mention Schneider here because this idea of communitybuilding and the possibility (or not) of the spectator to identify and commiserate with a collective body is closely related to Costa's own work and becomes evident in his own visual theorization of walls. If the "fourth wall" gave rise to realism in European theater and increasingly emphasized the limits of spectator involvement, it also somewhat paradoxically compels spectators-because the wall is there excluding them, even if it is only an abstract, transparent wall - to be conscious of its presence and thus of the possible connections and overlaps between themselves and the fictions and representations they witness. Walls are not simply material and functional; they are figurative. And while they seem to exclude and separate, they also forge connections and make possible a sense of identification, or lack thereof.

\section{Bridge and Door}

In his 1909 essay, "Bridge and Door," German philosopher and sociologist Georg Simmel reflects on how the notions of separateness and togetherness are correlated. He describes the sense with which two things must be apart to come together and how unity is only possible for things previously conceptualized as separate. Like Diderot's "fourth wall," which connects and divides, Simmel sees the bridge as the aesthetic symbol that most visibly and objectively ties together notions thought to be isolated. Furthermore, he maintains: "Whereas in the correlation of separateness and unity, the bridge always allows the accent to fall on the latter, and at the same time overcomes the separation of its anchor points that make them visible and measurable, the door represents in a more decisive manner how separating and connecting are only two sides of precisely the same act" (172). The door, according to Simmel, links the inner space of human experience and everything else that remains outside. However, precisely because the door can be opened, "its closure provides the feeling of a stronger isolation against everything outside this space than the mere unstructured wall. The latter is mute, but the door speaks" (172). 
For Simmel, there are differences between doors, walls, and even windows. The latter, for example, is made only for looking out of, and in its unidirectionality it is on fundamentally different footing from a door, which serves for Simmel as a bidirectional boundary between the finitude into which we have entered and the infinitude of physical and metaphysical being. Simmel observes how the door creates this possibility of a permanent interchange; however, he does not consider walls to encompass a comparable sense of exchange. On the contrary, he explicitly opposes the door to the "dead geometric form of a mere separating wall" (173). Simmel's questioning of exchange is only intensified and made more complex when we consider, as Costa does, dividing edifices, particularly walls, as mediators of both separation and unity. I turn now from Diderot's intentions for his "fourth wall" and Simmel's architectural-sociological-philosophical divisions to elucidate Costa's cinematic treatment of walls, what I refer to as his "mural imagination."

\section{Costa's Mural Imagination}

In 2004, Costa gave a talk in Tokyo titled, "A Closed Door That Leaves Us Guessing." Jonathan Rosenbaum has written that he considers the title of Costa's talk to be both a literal and a figurative description of the latter's work, considering "how obsessed he is with doors and windows in his films" (206). In the Tokyo talk, Costa considers the first attempts at filmmaking, juxtaposing these to the first photographs, and he discusses what he believes are some of the intrinsic attributes and functions of cinema. These include the idea that films ought to keep secrets, make us feel something is not right, and that cinema is an art of absence. As Costa puts it: "For me, the primary function of cinema is to make us feel that something isn't right. There is no difference between documentary and fiction here" (486). The title of the talk refers to the final scene of Ossos: a young girl closes a door just before the film ends. Costa claims that by closing this door, he keeps the spectator out: "there's a girl who closes a door and who looks at you, and the door is closed on you" (488). For Costa, this means we cannot enter the film's world; however, by closing the door, the film emblematically opens something up to us, including possibilities for other narratives, which even if secret are also made available to spectators by the mere fact that they are given a place to hide. 
Costa's first feature film, $O$ sangue, is also full of secrets. As Philippe Azoury describes it: "Eis um filme que sabe guardar um segredo. Nunca diz as coisas que o trabalham, em vez de as dar a entender prefere fazer-nos vê-las como num delírio:" (88). If Azoury prefers to compare the film to a dream, Adrian Martin argues that $O$ sangue is a film with an interior life: "O seu mistério e segredo não são algo de estudado, ou algo que seja acrescentado ao filme, como um estilo ou um maneirismo (como acontece tantas vezes). O que vemos a desenvolver-se em cada um dos seus filmes, e também através deles, é um estranha vida interior" (96). The film, shot in black-and-white, tells the tragic story of seventeen-year old Vicente and his ten-year old brother, Nino, who must fend for themselves in the wake of their father's death. Vicente's childhood friend Clara helps them in their struggles against their uncle and their father's creditors. Just like the secret that Clara never reveals to Nino, the film does not disclose to its spectators many of its plot's secrets and riddles, such as the father's ambiguous illness, his mysterious cause of death, or the nature of his financial difficulties. We do not always know what connects characters, what their background is, or where the future will take them. These barriers are set up metaphorically, as if they were walls built to hold the spectator at a distance and keep much of the story unknown, unexplained, and absent.

If we take a close look at the different forms of walls in the film, however, we find that they reveal and disclose implicit narratives and meanings, even if only through allusions. They are not merely keeping the viewer out but are also inviting us inside the untold story. The film's interior settings, within a schoolhouse and private houses, focus attention on the walls, which are almost always framed by windows and doors. These walls are old, faded, and with much of their plaster falling off. This is perhaps to be expected, since these walls belong to decaying houses and buildings in a small, poor, riverside town in Portugal. Many walls show the signs of water damage, which is reinforced by the sounds of the thunder and rainstorms at the beginning of the film, and by the repeated water imagery throughout the picture. Azoury in fact refers to the ubiquity of water in $O$ sangue, going so far as to call it a liquid film (84). The action, furthermore, takes place during the winter, covering the brief time between Christmas and New Year's Eve. Despite their weathered condition, these crumbling walls seem to tell a story, to give depth and historical background to the characters, as if human lives were reflected in the cinematic 
materiality of the walls that surround them. Put another way, these walls contain the missing biographical and affective context that the film silences. Their weathered appearance contrasts starkly with the children who often stand in front of them, such as the young Rosa of the opening sequence, a child with a

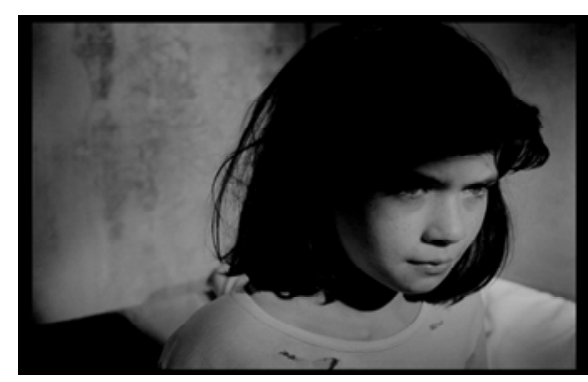

Image 1

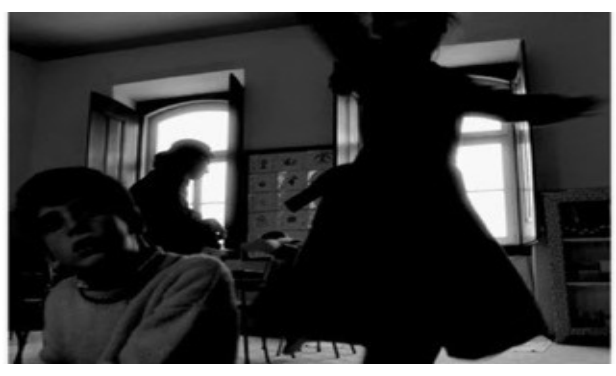

Image 2

habit of running away (Image 1), or Clara's distracted schoolchildren (Image 2). The walls surround, enclose, and hold together these innocent children and the main characters alike, creating a sense of structure amid their existential disorientation. Walls in $O$ sangue give form to the inner world of the film's characters, as if their material presence held the preconscious state of the people they surround, giving them psychological, emotional, and historical depth.

In addition to the walls that make up the domestic and interior spaces of the film, there is another level of enclosing that takes place within walls. This is achieved through exterior shots focused on a large garden (Image 3) and the stone walls that line the streets of the town (Image 4). The closed-in sense that

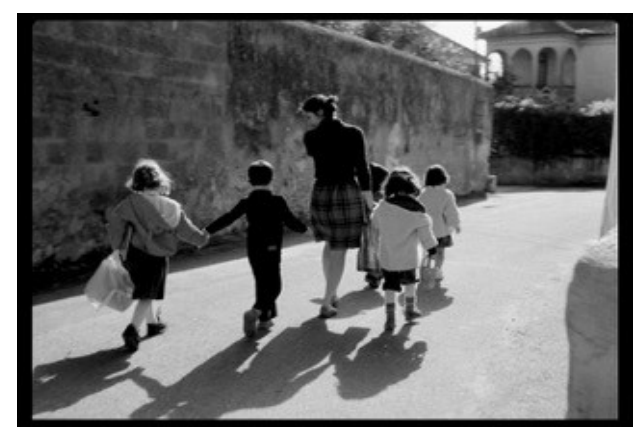

Image 3

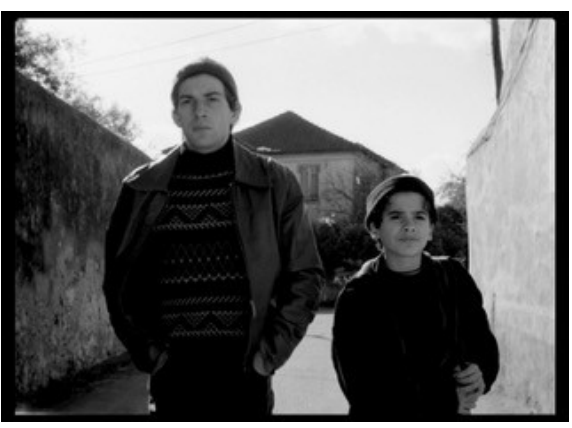

Image 4 
the camera and the reluctant narrative reveals or hides finds expression in the walled-in spaces that contain the characters within their small town. It is for this reason that the characters cannot simply go outside of their homes or school to confront the outside world - they must also cross the bridge that connects their riverside town to what lies beyond it (Image 5). In several scenes within the film, a bridge in the background emerges as an important marker that symbolically connects the small town's contained landscape with the external world (Image 6). Once Nino has been taken by the boys' unscrupulous uncle,

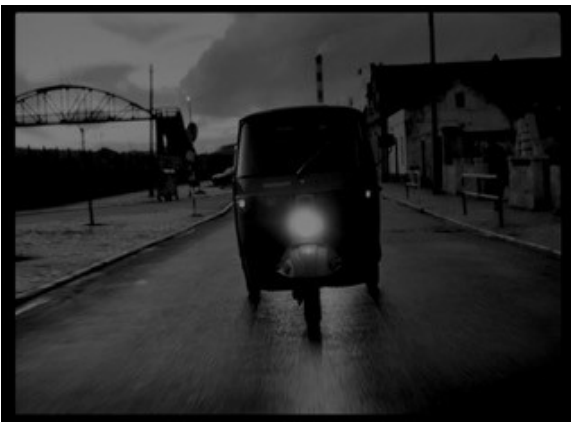

Image 5

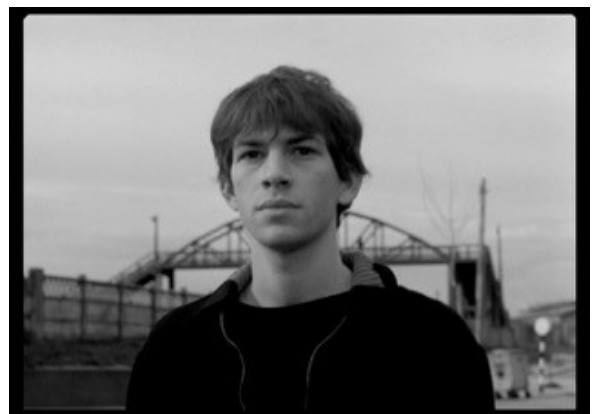

Image 6

Vicente must cross the bridge of a Lisbon apartment building to recover his brother; it is here that his father's creditors take hold of him and he enters a precarious liminal reality of danger and risk (Image 7). One may add to this that

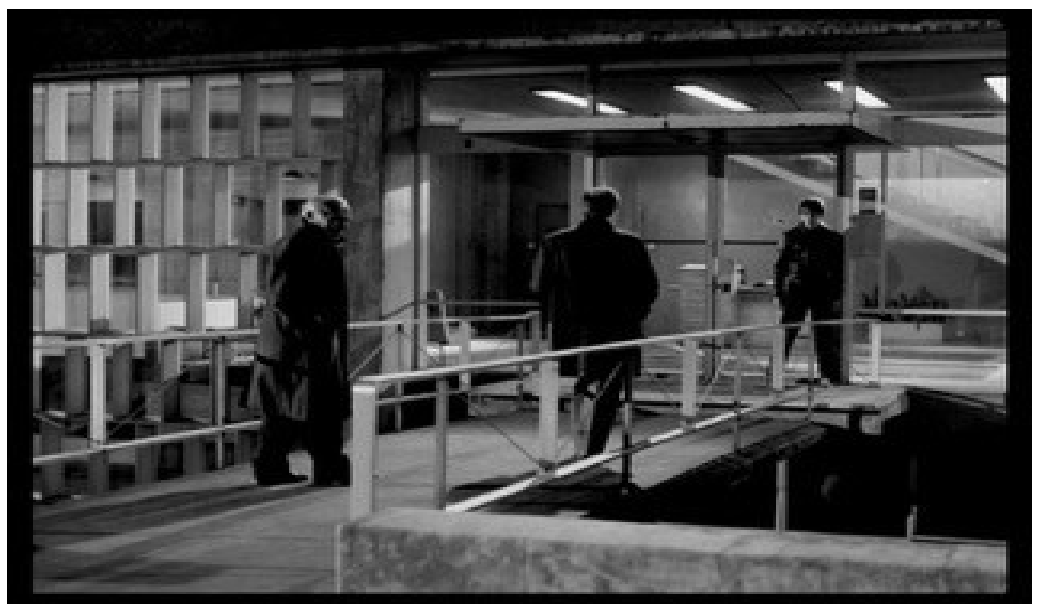

Image 7 
the father's abandonment of his sons (first by leaving them alone at home and then through his death) is prefigured in two exterior shots: in the first, he sits in the doorway of their house (Image 8); and in the second, he walks away from the town, down the narrow the narrow streets lined by the walls of other people's homes (Image 9). The interior world formed by these walls seems to

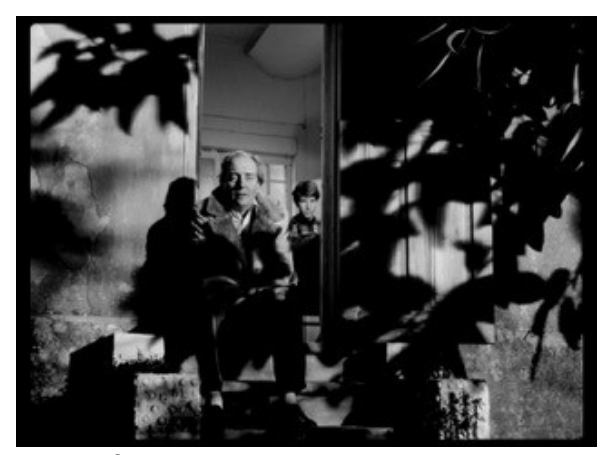

Image 8

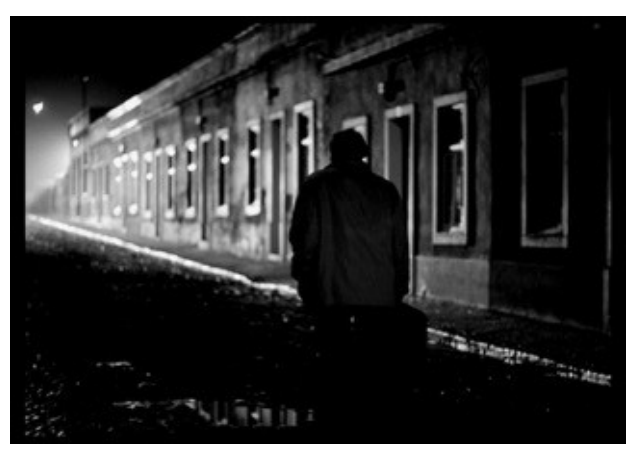

Image 9

stand for the characters' preconscious state; yet, their simultaneously protective and overpowering presence emphasizes the fact that the children are also forced to abandon these enclosed worlds. The walls close and open worlds, whether we understand these to be geographical, emotional, or psychological in nature. Like Diderot's fourth wall or Simmel's bridge, Costa's walled-in sets recreate the realm of innocence that the children inhabit, while also emblematically revealing this realm's precarity. $O$ sangue points to the fact that despite being thick and centuries old, these walls are also easily bridged or broken down.

Simmel describes walls as mute; however, Costa's walls are anything but silent. Despite their state of aged disrepair, they are dynamic, colorful, and imaginative. They consistently convey a sense of movement and depth. Resembling artworks or makeshift creative sketches, they challenge viewers to reflect on the role of the visual, and thus the cinematic. The film's walls, when not simply stonewashed and wilted, are frequently painted like murals, as in the case of the walls of the lower floor of the garage where Vicente works with other young men in a smuggling business that is never fully explained (Image 10). On the top floor of that same garage, the walls have a faint drawing of sea imagery, including fish and coral reefs (Image 11). Similarly, the walls in the 


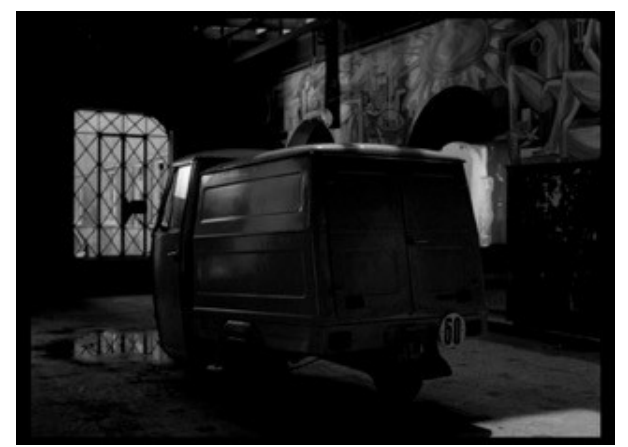

Image 10

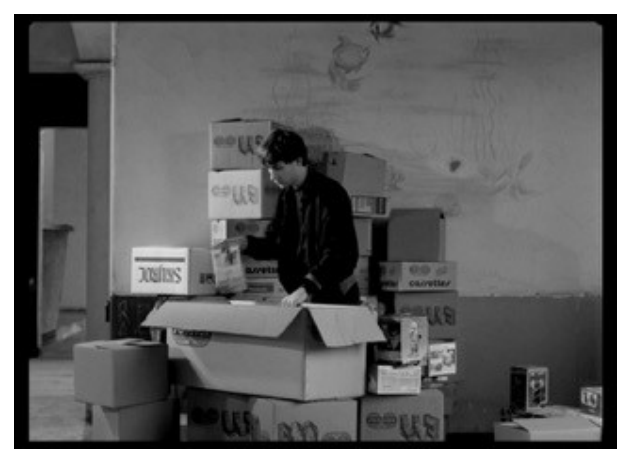

Image 11

Lisbon apartment building where Vicente's uncle lives with his son Pedro are also full of drawings (Image 12). The film makes these otherwise colorful drawings appear worn out, and like the film itself, they have lost their color. On the one hand, these painterly walls clearly accentuate the film's reflection of itself. Read as a meta-cinematic meditation, they attempt to create visual worlds, or movie screens, which at the same time, speak and silence, communicate and hide. On the other hand, the sea imagery in the clandestine garage prefigures the more vibrant visuals one finds in the scene shot in the Vasco da Gama Aquarium, where the boys' uncle takes Nino and his own son, Pedro (Image 13). Once again, the visual tableau is one of innocent children moving before imposing walls. This suggests that the sea is emblematic of the

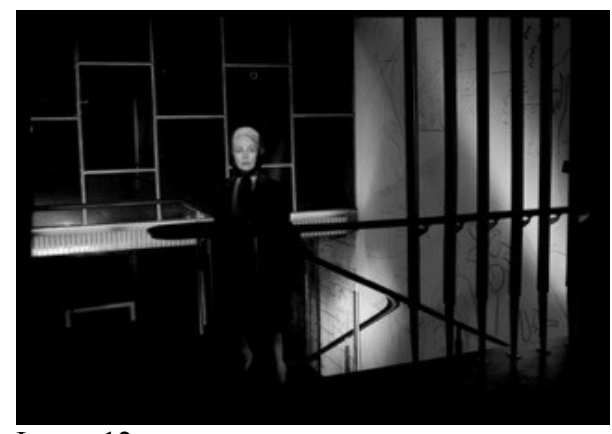

Image 12

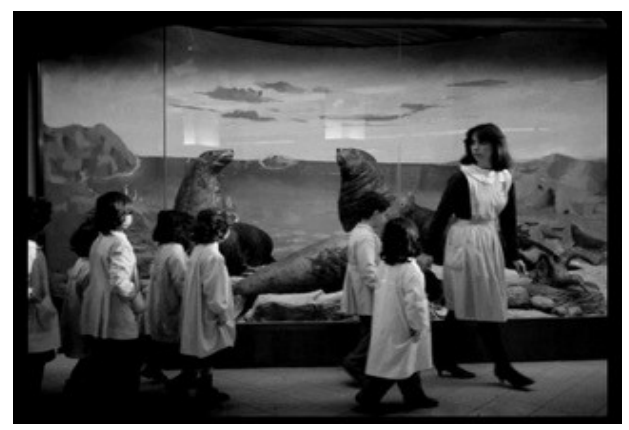

Image 13

space in which these children live, and that the sea's asphyxiating and limitless qualities resemble the characters' existence. These painted walls, even if presented as figures of entrapment and separation, are in fact designed to 
connect with the spectator, to speak silently, visually, figuratively, and create links between the film's protagonists and ourselves. They invite us not only to question and reflect upon notions of visual aesthetics but also to identify with these characters and their troubled lives.

Pedro, the uncle's handicapped child, does much the same. Despite his inability to speak, Pedro (who perhaps not incidentally has the same first name as the filmmaker), communicates a good deal of emotion through his silence, and even more so through the decorative wall of his bedroom (Image 14). The

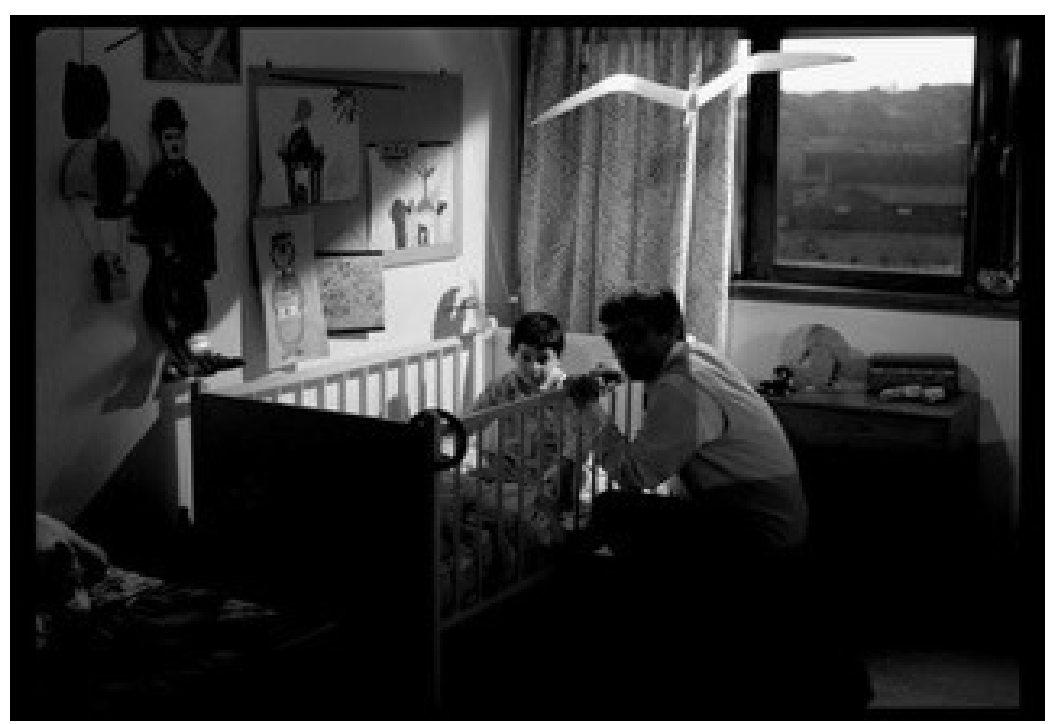

Image 14

drawings, the hot-air balloons, smiling bears, and Charlie Chaplin and bird cutouts, speak to us of cinema, escapism, innocence, imagination, and freedom. The film's cinematic walls communicate to the viewers via their silences and allusions, giving form to absence. Viewers are drawn in and made conscious of the messages encoded on these mute walls, and we are also called to reckon with the borders they symbolize. In this way, they underscore the multiple thresholds the film sets up and relies on for its ambivalent narrative; encounters between reality and dreams, old and young, beauty and disgust, love and hate, innocence and guilt, life and death, and finally, pre-consciousness and consciousness. In Costa's film, walls and their frames, windows, doors, and 
gates simultaneously separate these tensions and contraries while also bringing them together, much as Simmel does in his sociological readings of architectural structures. This emerges in the scene where Nino sits up against the back of Pedro's crib, a moment of tremendous emotional empathy between the two boys despite the wall created by the cage-like crib that separates them (Image 15). Similarly, when Clara and Nino stand by the windowsill of their house, one inside and the other outside, they establish an enduring bond in large measure through their separation (Image 16).

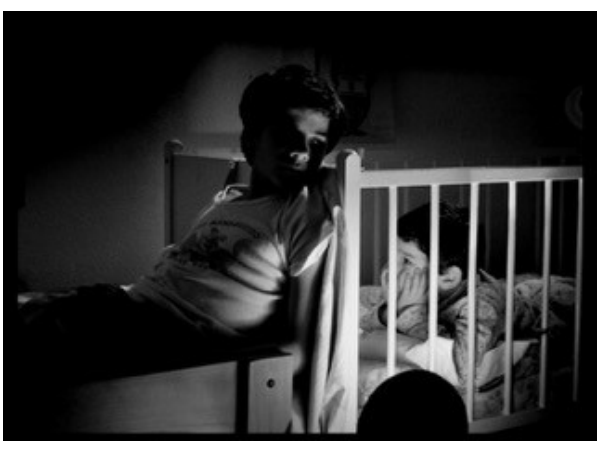

Image 15

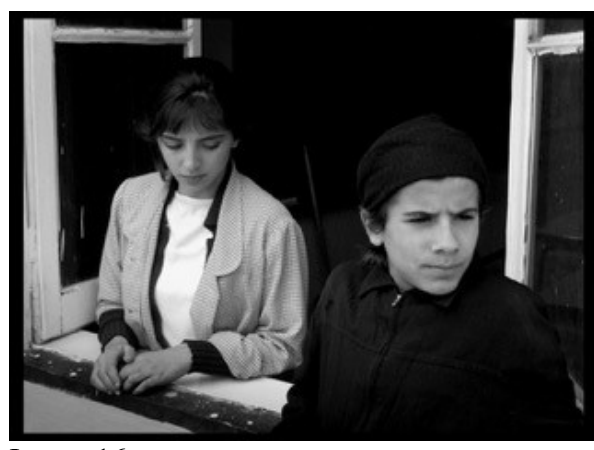

Image 16

The cinematic walls that separate and connect characters, viewers, and filmmakers together, bonding them in their visual experience precisely by bringing them apart, are not only visual or structural but also methodological. The film begins with two intense moments that emphasize Costa's use of walls to invite viewers in while also shutting them out. When Clara makes her first appearance in the film, she is running toward the camera. On her right is a barbed wire fence that gives a sense of exclusion and division to a scene that also surprisingly creates closeness as she runs into Vicente's arms (Image 17). Wire fences and stone walls accompany the couple throughout their endeavors. For example, Clara and Vicente must break down and cross a barbed wire fence to enter the cemetery where they bury Vicente's father (Image 18). The metaphoric walls and bridge are emblematic of the adventures and dangers that Vicente and Clara encounter. This is also evident the night the couple attends the town's festival. Clara enters by crossing a wall, slipping, and trying to keep 


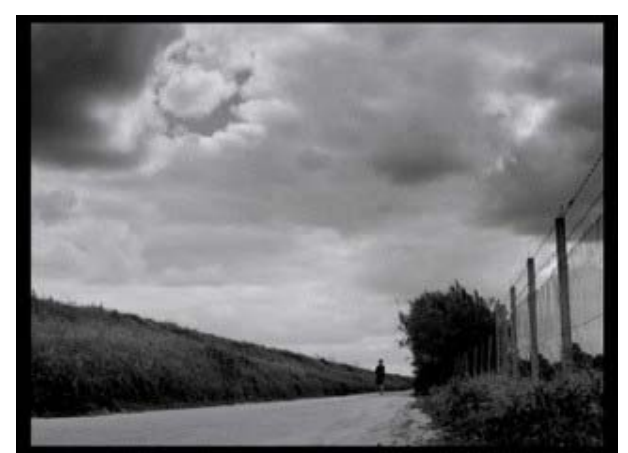

Image 17

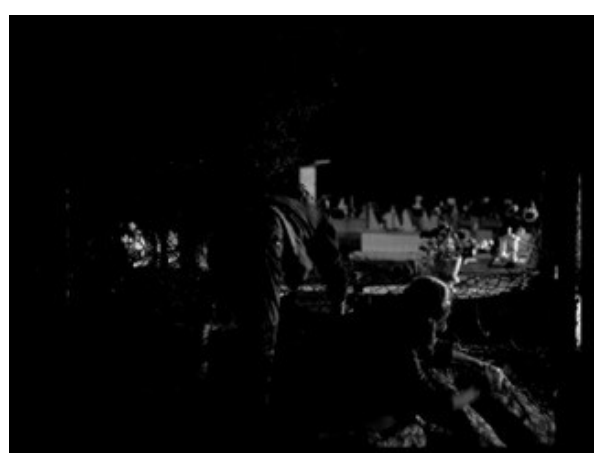

Image 18

her balance (Image 19). Like both Clara and Costa, the viewer is required to walk or cross over walls that take characters on journeys and into mysterious depths of experience. The film's narrative plot is also, not incidentally, about

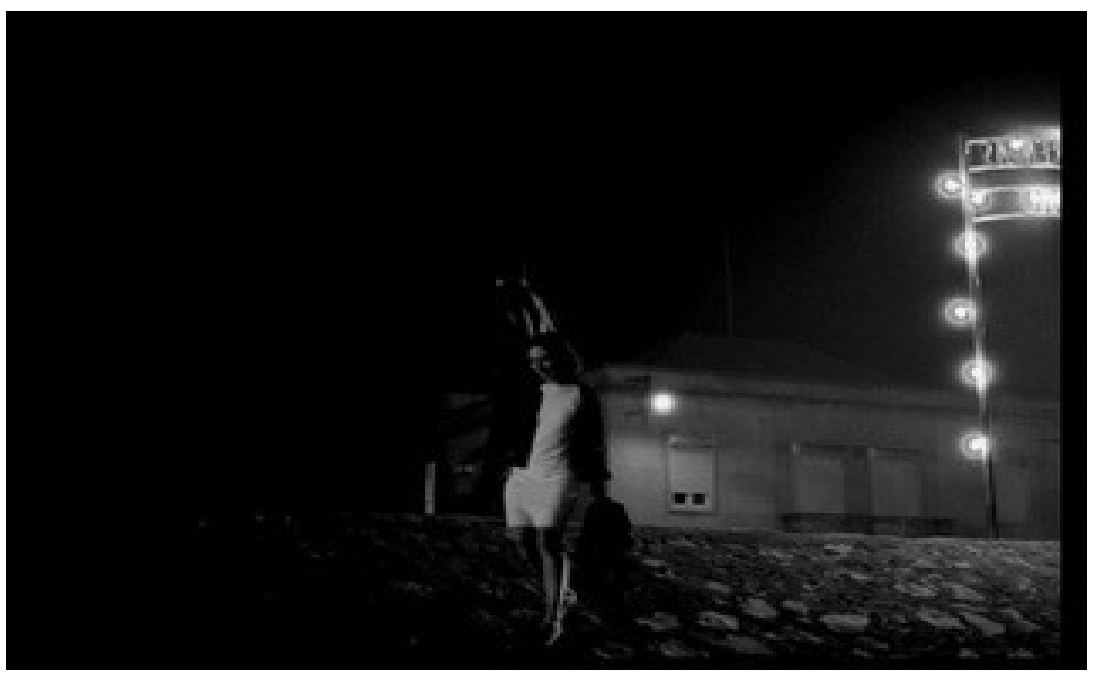

Image 19

separation and coming together, in that Clara and Vicente work assiduously to reunite with Nino after he is taken away by the boys' uncle.

Costa does not break the "fourth wall" in any conventional way in $O$ sangue. His characters do not talk directly to the spectator, but the film is nonetheless self-consciously aware of this permeable line. Costa in fact calls attention to this imaginary border in subtle ways. His mural imagination and the 
distinct functions he attributes to the figure of the wall, both in a metaphorical and meta-cinematic sense, are powerful forms of questioning the threshold between fiction and reality. They are also central to creating a notion of a community with which viewers might sympathize, as Schneider claims is the novelty or modernity inherent in Diderot's concept. To elucidate this, one needs only to focus on the first and last scenes of the film. $O$ sangue opens and closes with a parallel formal structure that speaks of the walls that construct the film. The opening scene establishes a confrontation between Vicente and his father. As throughout the film, there are important quotations of cinema history present in this opening, such as the American western and Robert Bresson's Mouchette (1967). The scene surprises the viewer because Vicente's father slaps him. This slap, however, comes from the other side of the camera, from the other side of the wall, as it were. The viewer is thus involved and fully integrated into a struggle with the narrative from the very start. In fact, this opening scene sets the tone for our engagement with the film, which is one of antagonism. Just as Costa claimed in his Tokyo talk that the little girl shuts the door on the spectator at the end of Ossos, here it appears the viewer has slapped Vicente or otherwise feels as if $\mathrm{s} / \mathrm{he}$ has been slapped as well. The conflict denotes the confrontation between the filmmaker and his creation as much as it alludes to an opposition between film and audience. Many critics (Azoury, Malveira, Martin, among others) have noted $O$ sangue's constant quoting of film history, claiming this to be a particularly important characteristic of Costa's first feature. As Azoury puts it, Costa employs intertextuality as if his goal were to raise cinema's ghosts from the dead. Costa brings his models to the fore to shut them out, or to bury them, just as Vicente buries his own father. The opening clearly recreates the tension the filmmaker feels with his artistic models, while it also imposes on the viewer a frictional connection to the visual and to cinema. This building of walls to keep spectators out while in fact inviting them in would only continue and intensify throughout Costa's filmography.

The closing scene of $O$ sangue returns to the idea of distance and closeness between the film's fictional story and the life or reality beyond it. After escaping from his uncle, Nino moves down the Tagus River on a fisherman's boat, returning home from his epic journey through Lisbon (Image 20). We hear the voice of the boatman speaking from the other side of the "fourth wall." At the end of the film, Nino appears in control of his destiny, as the fisherman 
asks him to take control of the boat's tiller. As Pereira argues: "O último plano do filme mostra Nino no controlo de uma embarcação, como se naquele momento ele mesmo fosse o homem do leme. Há uma certa segurança e esperança no rosto da criança, agora aparentemente mais madura. Contudo, até aqui uma sensação de confusão e incerteza prevalece. Há esperança de salvação mas a ameaça continua presente" (5). The connection between the boat's tiller and the camera strongly suggests that Costa wishes to break down the differences, or the walls, between the fiction and his characters and his reality as creator and empathizer.

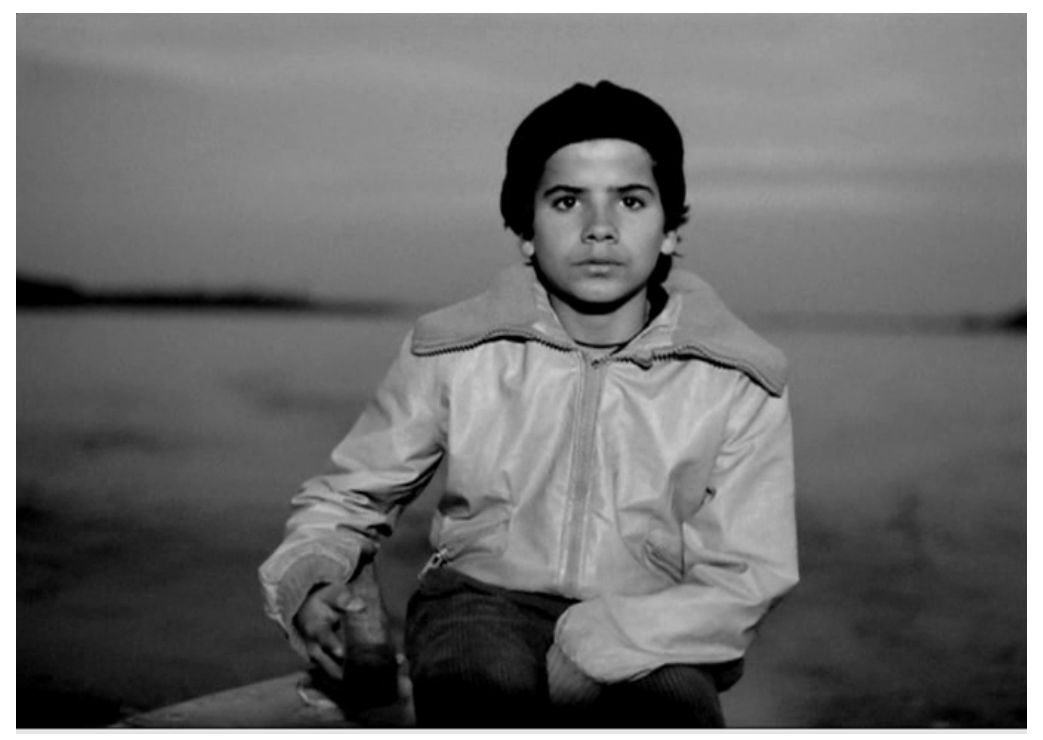

Costa's cinematic walls, whether real or formal, eroded or colorfully decorated, provide a way to theorize not only the visual and the cinematic but also our sense of community. This imaginary wall that speaks to the spectator of confrontation and impenetrability, but also of a tense relationship between the creator and his work, reinforces the idea that in Costa walls are integral to the director's conceptualization of images. To a certain extent, Costa returns to Diderot's original intentions. He builds walls between artists, actors, and the viewers, but he does this mainly to emphasize the authenticity of the fictional worlds he portrays and highlight the ways with which we engage and connect with them. The walls stand as a reminder to audiences that art is real, natural, 
and organic, and not merely pleasing entertainment that we can dictate, interact with, or manipulate. These cinematic borders oblige the spectator in significant ways. They draw the filmmaker and the film's content - the individuals and stories that populate it - into a conflicting interrogation that involves a questioning of how the separate and the disconnected come together.

\section{Works Cited}

Azoury, Philippe. "Órfãos." Cem mil cigaros: os filmes de Pedro Costa, edited by Ricardo Matos Cabo, Orfeu Negro, 2009, pp. 83-90.

Cipriano, Miguel. "Identitade e descentramento em Pedro Costa." Novas $e$ velhas tendências no cinema português contemporâneo, edited by João Maria Mendes, Gradiva, 2013, pp. 481-85.

Costa, Pedro. "A Closed Door That Leaves Us Guessing." Novas e velhas tendências no cinema português contemporâneo, edited by João Maria Mendes, Gradiva, 2013, pp. 485-500.

—. Letters from Fontainhas: Three Films by Pedro Costa. Criterion, 2010.

Diderot, Denis. "De la poésie dramatique." Oeuvres esthétiques, Garnier, 1994.

Gottlieb, Akiva. "A Cinema of Refusal: On Pedro Costa." The Nation, 11 Aug. 2010, www.thenation.com/article/cinema-refusal-pedro-costa/.

Malveira, Bruno. O cinema suspenso de Pedro Costa. Dissertation, U Católica Portuguesa, 2011.

Martin, Adrian. "The Inner Life of a Film." Cem mil cigaros: os filmes de Pedro Costa, edited by Ricardo Matos Cabo, Orfeu Negro, 2009, pp. 91-98.

Pereira, Sara Raquel Pinto. "O sangue: um filme de Pedro Costa." MA Thesis, U Nova de Lisboa, 1989.

Rosenbaum, Jonathan. Goodbye Cinema, Hello Cinephilia: Film Culture in Transition. U of Chicago P, 2010.

Schneider, Helmut J. "Humanity's Imaginary Body: The Concepts of Empathy and Sympathy and the New Theater Experience in the $18^{\text {th }}$ Century." Deutsche Vierteljahrsschrift, vol. 82, no. 3, 2008, pp. 382-99.

Simmel, Georg. Simmel on Culture: Selected Writings, edited by David Frisby and Mike Featherstone, Sage, 1997. 